\title{
The Alternative Strategy For Strengthening Indonesian Textile and Clothing Industry Structure
}

\author{
ALLA ASMARA ${ }^{1}$, YETI L. PURNAMADEWI ${ }^{1}$, SRI MULATSIH $^{1}$, TANTI NOVIANTI $^{1}$ \\ ${ }^{1}$ Department of Economics Science, Faculty of Economics and Management, IPB, Bogor 40123, Indonesia \\ Emailcorrespondence: allasmara@yahoo.com,yetilispurnama@yahoo.com, mulatsupardi@yahoo.co.id, tantinovinati@yahoo.com
}

\begin{abstract}
Indonesian textile and clothing industry (TPT) is an industry most affected by markets dynamics growing (domestic and international). Strengthen the industrial sector is important aspects to guarantee the existence of Indonesian TPT industry. The purposes of this study are: (1) analyze the internal factors (strengths and weaknesses) of Indonesian TPT industry, (2) analyze the external factors (opportunities and threats) of Indonesian TPT industry, (3) formulate the alternative strategies to strengthen the Indonesian TPT industry, and (4) formulate the priority strategies to strengthen the Indonesian TPT industry structure. SWOT and QSPM method used to answer the research objectives. The study results indicate that raw material is key factor for strengthening Indonesian TPT industry structure. Other key factors are human resource, infrastructure, market/marketing, product, production process, strategy/policy, and financial. On the internal side, the main strength is a variety of raw material alternative sources, while the main weakness is not always able to guarantee the raw material quantity, quality, and continuity. On the external side, international market product price tends to increase considered as major opportunity. Meanwhile, the main threat is in the high level of competition in domestic/international market. According to internal and external conditions, the position of Indonesian TPT industry in SWOT quadrant is in quadrant II, has strength but facing threat.
\end{abstract}

Key words: external factor, internal factor, strengthening strategy, textile and clothing industry

\section{Strategi Alternatif Untuk Memperkuat Tekstil Indonesia dan Struktur Industri Pakaian}

\begin{abstract}
Abstrak
Tekstil Indonesia dan industri pakaian (TPT) merupakan industri yang paling terpengaruh oleh pasar dinamika yang berkembang (domestik dan internasional). Memperkuat sektor industri aspek penting untuk menjamin keberadaan industri TPT Indonesia. Tujuan dari penelitian ini adalah: (1) menganalisis faktor internal (kekuatan dan kelemahan) industri TPT Indonesia, (2) menganalisis faktor-faktor eksternal (peluang dan ancaman) industri TPT Indonesia, (3) merumuskan strategi alternatif untuk memperkuat industri TPT Indonesia, dan (4) merumuskan strategi prioritas untuk memperkuat struktur industri TPT Indonesia. SWOT dan metode QSPM digunakan untuk menjawab tujuan penelitian. Hasil penelitian menunjukkan bahwa bahan baku merupakan faktor kunci untuk memperkuat struktur industri TPT Indonesia. Faktor penting lainnya adalah sumber daya manusia, infrastruktur, pasar / pemasaran, produk, proses produksi, strategi / kebijakan, dan keuangan. Di sisi internal, kekuatan utama adalah berbagai alternatif sumber bahan baku, sedangkan kelemahan utama tidak selalu dapat menjamin kuantitas bahan baku, kualitas, dan kontinuitas. Di sisi eksternal, harga produk pasar internasional cenderung meningkat dianggap sebagai peluang besar. Sementara itu, ancaman utama adalah di tingkat kompetisi yang tinggi di / pasar internasional domestik. Sesuai dengan kondisi internal dan eksternal, posisi industri TPT Indonesia di SWOT kuadran berada pada kuadran II, memiliki kekuatan tapi menghadapi ancaman.
\end{abstract}

Kata kunci: faktor eksternal, faktor internal, memperkuat strategi, industri tekstil dan pakaian. 


\section{INTRODUCTION}

Globalization has pushed the market dynamics of the industry products becoming increasingly competitive. Indonesian textiles and textile products industry (TPT) is one of the industries most affected by the dynamics of the market (domestic and international) that are growing. The textile products from other countries, particularly China, increase the competition in domestic market. Meanwhile, in the international market competition is also likely to increase. Moreover, in Europe, competition between the textile industries referred to as a very intense international competition (Bilalis et al, 2006). Asmara et al. (2013a) revealed that in the map of world trade in the last five years (2008-2012), China is a major exporter of products that tend to dominate the world textile market. The same thing also expressed by MacDonald, et al. (2004). Beside China, other Asian countries that also have become the exporter of textile products are: South Korea, Hong Kong, Japan, and India.

The importance of the textile industry sector in the Indonesian economy is indicated by the industry's contribution in the formation of GDP, employment and foreign exchange (Asmara et al, 2013a). Besides its role in national economy growth, the textile industry is also focused to meet the needs of national clothing (Ministry of Industry, 2013). The critical role of the textile industry in the economy is also found in many countries such as China (Anonymous, 2005), Bangladesh (Khan et.al, 2008; Ahmed, 2013) and Vietnam (Kenta, 2007). Thus, it becomes very natural that every country seeks to continuously improve the competitiveness of their textile industry, including Indonesia.

On the other side, Hermawan (2011) reveals that the market dynamics of the textile industry products not only can be an opportunity for Indonesian textile industry, but also it can be a threat. The intense competition between the countries in the world textile producers, such as China, India, the United States and the European Union is a threat to the Indonesian textile industry. Issues of nontariff barrier, such as transshipment and dumping, also influence the penetration flow of textile trade from developing countries to developed countries.
Meanwhile, Firdaus (2007) revealed that the strength of the competitiveness of Indonesia's TPT is still under the power of the competitiveness of Chinese textile. Chinese fabric and yarn commodity have more comparative advantages. This is due to various factors that China has superiority in the production of goods and services compared to Indonesia. Haliding (2010) also revealed that the labor costs are almost the same, but Chinese laborers work more efficient, resilient and patient as well as more adequate skill.

Stemming from the phenomenon that exists, then increasing the competitiveness of Indonesia's textile industry needs to be encouraged. The structure of Indonesian textile industry is still characterized by the use of machinery and the outdated technology that need to be transformed in more competitive industry structure. In this context, strengthening the structure of the textile industry becomes very urgent to do. Mapping the position of Indonesian textile industry is based on internal and external factors that developed and the formulation of alternative strategies to strengthen the structure of the textile industry is the main objective of this study. More specifically, the purposes of this research are (1) Analyze the internal factors (strengths and weaknesses) of Indonesian textile industry, (2) Analyze the external factors (opportunities and threats) of Indonesian textile industry, (3) Formulate the alternative strategies to strengthen the structure of Indonesian textile industry, (4) Formulate theprioritystrategies for strengthening the structure of Indonesian textile industry.

\section{RESEARCH METHODS}

The main data used are primary data obtained through in-depth interview and Focus Group Discussion (FGD). In-depth interviews were conducted on the number of stakeholders in West Java and East Java with a structured questionnaire guide. In the implementation of FGD, stakeholders include: governments (ministry of industry and industrial departments of province/ district/city), academician, Indonesian Textile Association (API) and textile industry entrepreneurs that become informants. FGDs were held in West Java (Bogor City) and East Java (Pasuruan Regency) in September-October, 2014.

The analytical method used in this research are SWOT 
and QSPM analysis. SWOT analysis is used to map the strengths and weaknesses, opportunities and threats faced by the textile industry. SWOT matrix consists of Internal Factor Evaluation (IFE) and External Factor Evaluation (EFE). David (2006) revealed that the IFE Matrix is a formulation tool that can summarize and evaluate the major strengths and weaknesses of every industries. EFE Matrix is used for planning strategies and evaluating the information opportunities and external threats as well as various aspects related to the development of an industry.

Identification and determination of internal and external weight critical success factors (a key factor) accomplished by using the "Paired Comparison" (Kinnear and Taylor, 1996). To determine the weight of each of the key factors used a scale of 1,2 and 3 , with the following conditions (Table 1) (1) If the vertical indicator is less important than the horizontal indicator, (2) If the vertical indicator is equally important with horizontal indicator, (3) If the vertical indicator is more important than the horizontal indicator.

Table 1 Weight Rating of Internal and External Key Factors

\begin{tabular}{llllll}
\hline Internal Factor Strategy & A & B & C & $\ldots$. & Total \\
\hline A & & & & & \\
B & & & & & \\
C & & & & & \\
$\ldots$. & & & & & \\
Total & & & & & \\
& & & & & $\sum_{i=1}^{n} X i$ \\
\hline
\end{tabular}

Source : Kinnear and Taylor,1996

The weight of each key factors is obtained by dividing the total value of each key factors to the number of overall value, using the following formula:

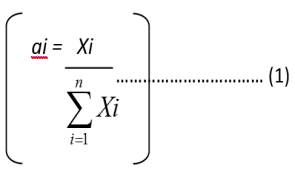

ai $=$ Weight of the key factors-i

$\mathrm{X} \mathbf{i}=$ Total value of the key factors-i

$\mathrm{i}=1,2,3$, ...n

$\mathrm{n}=$ Total number of key factors

Giving rating to the internal and external factors uses a scale of 1-4, with the following conditions (Table 2):
Table 2 Determining of the rating of internal and external factors

\begin{tabular}{ccccc}
\hline \multirow{2}{*}{ Rating } & \multicolumn{4}{c}{ Key Factors } \\
\cline { 2 - 5 } & Strength & Weakness & Opportunity & Threat \\
\cline { 2 - 5 } 1 & Rather strong & Rather weak & Rather big & Rather big \\
2 & Strong enough & Weak enough & Big enough & Big enough \\
3 & Strong & Weak & Big & Big \\
4 & Very Strong & Very weak & Very Big & Very Big \\
\hline
\end{tabular}

In general, the calculation of SWOT analysis includes three stages, namely: (1) The calculation of scores for each factor that is the multiplication of weight with the rating and sum of the total scores on each S-WO-T factors; (2) The reduction in the total number of $S$ and $\mathrm{W}$ factors with $\mathrm{O}$ and $\mathrm{T}$ factors. The difference in value of $S$ and $W$ factorsbecomes points on the $X$ axis, and the difference in $\mathrm{O}$ and $\mathrm{T}$ factorsbecomes points on the $Y$ axis; (3) The determination of Indonesian textile industry position is represented by point $(x, y)$ on the SWOT quadrant (Figure 1).

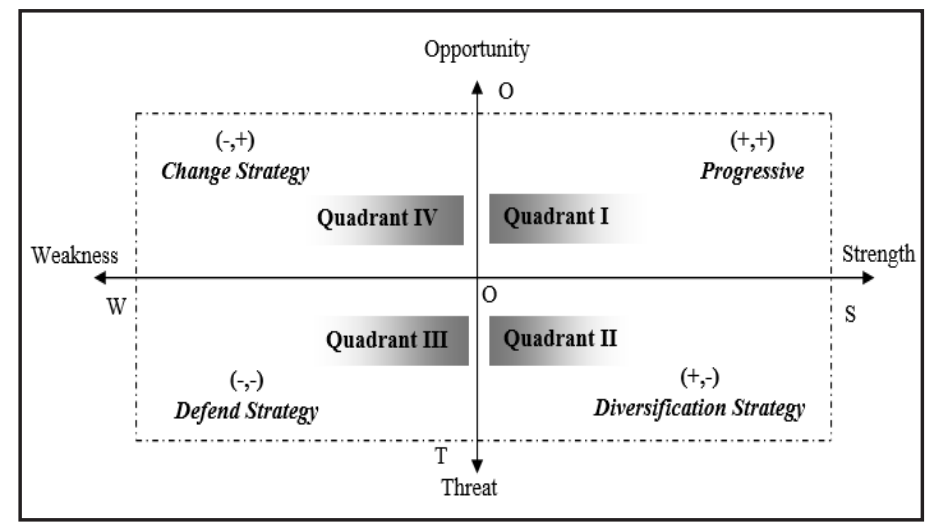

Source: Pearce and Robinson, 2004

Figure 1 SWOT Quadrant

QSPM analysis is used to rank the strategies resulting in a prioritized strategy to be implemented. QSPM or quantitative strategy planning matrix is a tool that allows strategists to evaluate alternative strategies objectively based on the internal and external key success factors that have been identified previously. Conceptually, QSPM determine the relative attractiveness of various strategies based on how far the internal and external key success factors used or repaired. The relative attractiveness of each strategies in a set of alternatives is calculated by determining the cumulative effect of each internal and external key success factors (David 2006). The basic format of the QSPM matrix can be seen in Table 3. 
Table 3 QSPM (Quantitative Strategic Planning) Matrix

\begin{tabular}{|c|c|c|c|c|c|c|c|c|c|}
\hline \multirow[t]{3}{*}{ Key Factors } & \multirow[t]{3}{*}{ Weight } & \multicolumn{8}{|c|}{ Alternative Strategies } \\
\hline & & \multicolumn{2}{|c|}{ Strategy 1} & \multicolumn{2}{|c|}{ Strategy 2} & \multicolumn{2}{|c|}{ Strategy 3} & \multicolumn{2}{|c|}{ Strategy .... } \\
\hline & & AS & TAS & AS & TAS & AS & TAS & AS & TAS \\
\hline \multicolumn{10}{|l|}{ External Factor } \\
\hline \multicolumn{10}{|l|}{ 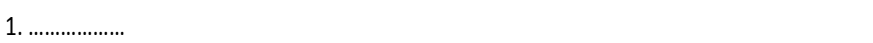 } \\
\hline \multicolumn{10}{|l|}{ 2. .......................... } \\
\hline \multicolumn{10}{|l|}{ 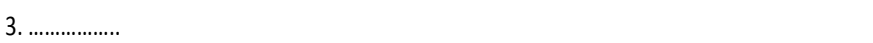 } \\
\hline \multicolumn{10}{|l|}{ Internal Factor } \\
\hline \multicolumn{10}{|l|}{ 1. ...................... } \\
\hline \multicolumn{10}{|l|}{ 2. ……............. } \\
\hline 3. ..................... & & & & & & & & & \\
\hline
\end{tabular}

Stages of data processing use QSPM methods (David 2006) are; (1) Make the list of opportunities and external threats and also internal strengths and weaknesses key in the left column of QSPM. This information is taken directly from EFE and IFE matrix. (2) The weighting for each internal and external factors. The weights are identical to that of the EFE and IFE matrix. (3) Matching phase and identification of alternative strategies that consider to the organization to be implemented. These strategies are recorded on the top row of QSPM. (4) Determine the value of attractiveness (Attractiveness ScoresAS), is defined as a number that indicating the relative attractiveness of each strategies in a certain alternative set. The value ranges of the attractiveness are 1 = not attractive, 2 = somewhat attractive, $3=$ quite attractive, 4 = very attractive. (5) Calculate the total value of the attractiveness (Total Attractiveness Scores-TAS), is defined as the result of multiplying the weight (step 2) with the value of attractiveness (step 4) in each row. The higher the total value of the attractiveness, the more attractive alternative strategies. (6) The Sum total of the attractiveness by adding the total value of the attractivenessin the respective columns of QSPM strategies. The sum total of the attractiveness (STAS) reveals which strategies are the most attractive of any set of alternatives. A higher value indicates a more attractive strategy, considering all the internal and external factors that are relevant to influence strategic decisions.

\section{RESULT AND DISCUSSION}

In the textile industry, there are five sub-sectors that were involved in doing the processing of raw materials to ready-made textile products. The fifth sub-sector of the industry is fiber industry, yarn industry, fabrics industry consisting of woven/ fabrics (weaving), knitting, and finishing, the apparel industry (garment), and other textile industries. Figure 2 shows the structure and characteristics of the textile and clothing industry (TPT) tree.

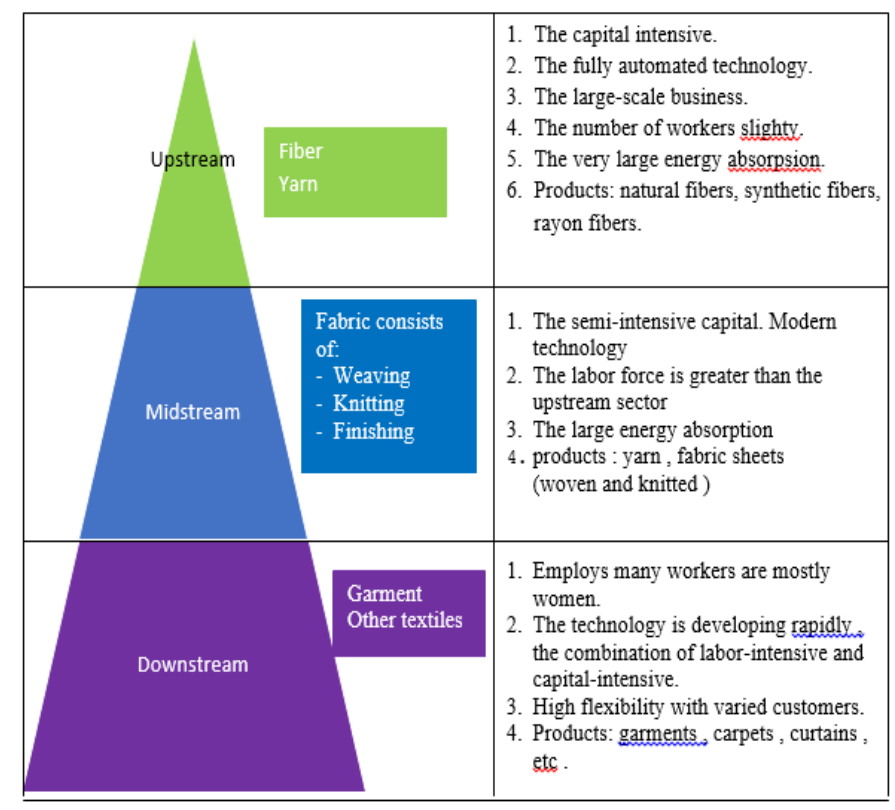

Source: The Indonesian Textile Association (API), 2011.

Figure 2 Tree of Textile and Clothing Industry

\section{The Key Factor for Strengthening Indonesian Textile and Clothing Industry Structure}

Based on the results of Focus Group Discussions, the key factors of Indonesia's TPT were identified as: raw materials, production processes, products, markets or marketing, human resources, infrastructure, financial or payment, and policy or strategy. The weight of each key factors based on the assessment done by the stakeholders (industry, government and academia) are presented in Figure 3.

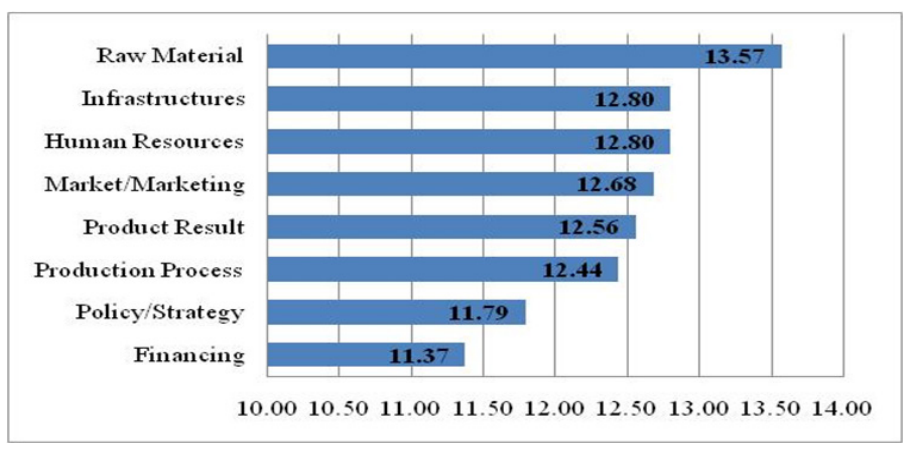

Source: Primary Data (Processed)

Figure 3 The Key Factor for Strengthening Indonesian Textile and Clothing Industry Structure 
JURNAL BISNIS \& MANAJEMEN

ISSN 1412 - 3681

The raw material is a key factor that is considered to be the most important for strengthening the structure of the Indonesian textile and clothing industry, with a weight of 13.57 . This is because the raw material is a factor of production that determines the quantity, quality and continuity of the products, so the availability of raw materials both in terms of quantity, quality, continuity and reasonable cost is essential for the competitiveness of the textile and clothing industry in Indonesia. However, industry actors revealed common problems related to raw materials. Asmara et al. (2013c) reveals that the issues related to raw materials, (availability, continuity and price) becoming the main problem faced by the textile and clothing industry.

The problem of raw material in the textile and clothing industry is closely related to the source of raw materials mostly sourced from imports. FGD obtained information that the raw material (fiber) used to produce textile more than 50 percent is imported. Meanwhile, the raw material, polymer, can be produced in Indonesia with limited amount of production. The production of fiber in the country, is expected by industry actors can fully distribute to the yarn company in Indonesia. In addition, the stability of raw material quality (fiber) which is used less good that can affect the quality and competitiveness of the resulting yarn. Increased investment is needed in the textile industry so that the stability of raw materials quality can be more assured. Asmara et al. (2013b) revealed that the raw materials auxiliary variable originating from within country has positive influence on the level of investment in the textile industry. This means that the increasing in the use of domestic raw material resources will increase the investment in the national textile industry.

Human Resources and infrastructure are the further key factors that are important for strengthening the Indonesian textile industry structure, with a weight of 12.8. According to Kadin Indonesia (2007), the textile industry is a combination of high-tech industries, capital intensive and skills of human resources (HR). Thus, the existence of skilled human resources is needed in strengthening the textile industry structure, especially in the textile industry subsector. In the FGD showed that the limitations of skilled workers, particularly in the textile industry, are the common problems faced by the industry. Limitations of skilled workers in the textile industry related to the limited higher education in the textile field. On the other hand, local government programs in improving the skills of prospective workers tend to be only sewing skills, while what needed by the textile industry is the ability of workers to operate the equipment/machinery production. This indicates that there's no synergy between local government and the textile industry so that employment opportunities can't be filled by local workers. Problems related to the availability of skilled labor is also experienced in India, NSDC (2011) states, there is still a skill gap of requires skill to some sub-sectors such as the textile industry in spinning industry, fabric manufacturing, fabric processing, and, garment.

Infrastructure and facilities support that are adequate also play an important role for strengthening the textile industry structure in Indonesia. Availability of basic infrastructure (such as electricity, water, roads/ bridges, transportation, and telecommunications) and infrastructure (such as machinery and production equipment) greatly affects the performance of the national textile industry. In the global competitiveness index, infrastructure is one of the pillars of competitiveness that is included in the basic requirement. In 2013, the condition of infrastructure in Indonesia is in the fifth lowest of the twelve pillars of competitiveness (World Economic Forum, 2013). This suggests that the increased availability of infrastructure, both in terms of quantity and quality needs to be improved. Asmara et al. (2013c) reveals that one of the problems related to the production aspect is a power outage. Power outages that are frequent make the textile industry increasing production costs and the production process to be interrupted.

The key factors that are related to the market/ marketing were in fourth position after the raw materials, human resources and infrastructure. This suggests that the ability in marketing and market control determined by the raw materials, human resources and infrastructure owned/ available to the textile industry. The availability of those factors will determine the competitiveness of textile products produced, so not only can compete in the domestic market but also in the international market. Asmara, 
Purnamadewi, and Meiri (2013) reveal that most of medium scale textile industries (94.59 percent) sell their products to domestic market. While on a large scale textile industries, most of them (43.48 percent) selltheir products to both domestic and foreign.

The product result is a key factor that is also considered to be important in strengthening the textile industry structure in Indonesia. Good quality product that is suitable for market demand trends and competitive prices become the challenges facing the national textile industry. In fact, according to the API, the quality of the domestic textile industry is already much better than imported products, so that it can meet domestic market share (Tresnaningtyas, 2009). While in China, the quality of Chinese textile products is relatively high, and provides the best value for the buyer (Anonymous, 2005).

Related to the production process, in a group discussion showed that there are problems in the production process as there are many companies that produce relatively old age machines, generally older than 10 years, so that the machines is less able to compete. In addition, the machinery technology used for Indonesian textile industry is already left behind competitor countries. Indonesia also has less innovation in making textile machinery so that there is dependency by buying machines from abroad (imports). The worker demands against wage continued to increase, labor demonstrations also become factors that disrupt the production process. Asmara (2013c) also revealed that the production problems caused by power outages, employees often do not come to work, the high level of out-ofentry (turnover) labor and unskilled labor, causing decreases in production.

Strategies of textile industry as well as government policy have also become one of the key factors needed in strengthening the textile industry structure. Textile industry strategies (includes: product, price, distribution systems, promotion, and innovation) will determine the ability of the textile industry to face the competition. In addition, the support policy/government program will also determine the development of national textile industry. Machine restructuring program is a program launched by the government. The program is considered to be sufficient to help the textile industry, although there are still some obstacles in its implementation in the area.

The key factor that is also considered to be important for the strengthening of the structure of the textile industry in Indonesia is financial. In the group discussion showed that the financial support from the government is still urgently needed by the textile industry, whether for small-scale medium textile industry or large industries. The financial support, especially for purchasing new machines/rejuvenated machines. In addition, the textile industry became one of the industry that obtain the largest financing contribution of Indonesian Export Financing Agency (LPEI) or Indonesia Exim bank (Nur, 2013).

Table 3 Matrix of Strengths Analysis of Indonesian Textile Industry

\begin{tabular}{|c|c|c|c|c|c|}
\hline Key Factor & Weight & Strength & Weight & Rating & Value \\
\hline Raw Material & 13,19 & $\begin{array}{l}\text { Industry has a variety of alternative sources of procurement of raw materials (domestic and } \\
\text { imported) }\end{array}$ & 13,57 & 3 & 0,37 \\
\hline Human Resources & 13,10 & Industry has an adequate number of workers & 12,80 & 3 & 0,35 \\
\hline Infrastructures & 13,19 & Most industries have an adequate industrial machineries and tools & 12,80 & 3 & 0,34 \\
\hline \multirow{2}{*}{ Market/Marketing } & \multirow{2}{*}{12,30} & Industry has the experience and ability to market the products & 6,34 & 3 & 0,19 \\
\hline & & Most of the industries has sufficient marketing network in the domestic market & 6,34 & 3 & 0,17 \\
\hline \multirow{4}{*}{ Product Result } & \multirow{4}{*}{12,50} & $\begin{array}{l}\text { Most industries can produce quality productsthat meet the standards of national/ international } \\
\text { market }\end{array}$ & 3,14 & 3 & 0,10 \\
\hline & & Industry can produce products according to consumer preferences & 3,14 & 3 & 0,10 \\
\hline & & Industry is able to produce the products continuously & 3,14 & 3 & 0,10 \\
\hline & & Industry has an innovative product design capability & 3,14 & 3 & 0,08 \\
\hline \multirow{2}{*}{ Production Process } & \multirow{2}{*}{12,20} & Most industries have the ability to adopt technologies that continue to develop & 6,22 & 3 & 0,17 \\
\hline & & Most of the industries uses an efficient modern technology & 6,22 & 3 & 0,18 \\
\hline
\end{tabular}


ISSN 1412 - 3681

Continue of Table 3 Matrix of Strengths Analysis of Indonesian Textile Industry

\begin{tabular}{|c|c|c|c|c|c|}
\hline Key Factor & Weight & Strength & Weight & Rating & Value \\
\hline Policy/Strategy & 12,00 & Most industry has strategies to face the competition & 11,79 & 3 & 0,31 \\
\hline Total & 100,00 & & 100,00 & & 2,77 \\
\hline
\end{tabular}

Source: Primary Data (Processed)

Analysis of Internal Factors of Indonesian Textile Industry

Identification of internal factors (strengths and weaknesses) for each key factors is presented in Table 3 and Table 4. "Industry has variety of alternative sources of procurement of raw materials (domestic and imported)" is the main strength factor of the textile industry. However, the disadvantage faced in terms of raw material is "not always able to guarantee the quantity, quality and continuity of raw materials as needed". Asmara et al. (2013c) showed that there are 30.42 percent of the textile industry and 29.73 percent of textile products industry still facing problems related to the procurement of raw materials. Related to the continuity of raw materials, there are 26.09 percent of the textile industry and 18.92 percent of textile products industry that still facing problems. weaknesses facing the textile industry. Therefore, improvement of human resources skills needs to be pursued by both government and industry. In order to provide the needs of the workforce, since 2011 the Ministry of Industry, along with the Association of Textile Industry has conducted training programs, certification, and placement in the garment industry, held in the halls of Human Resource Development and Training Center Industry in Java (Anonymous, 2014). In addition, Kemenakertrans did internship programs to Japan for 2,500 Indonesian workers, like vocational field of textile industry. The internship program can help the workforce absorbed in the job market, because the program provides appropriate skills to labor market needs and also work experiences with a variety of conditions of employment in the company (Anonymous, 2013).

Table 4 Matrix of Weaknesses Analysis of Indonesian Textile Industry

\begin{tabular}{|c|c|c|c|c|c|}
\hline Key Factor & Weight & Weakness & Weight & Rating & Value \\
\hline Raw Materials & 13,19 & $\begin{array}{l}\text { The industry does not always guarantee the quantity, quality, and continuity of raw material } \\
\text { obtained in accordance with the required }\end{array}$ & 13,57 & 2,93 & 0,40 \\
\hline \multirow{2}{*}{ Human Resources } & \multirow{2}{*}{13,10} & The number of skilled workforce is relatively limited & 6,40 & 3,00 & 0,19 \\
\hline & & Human Resources productivity in the textile industry is still relatively low & 6,40 & 2,93 & 0,19 \\
\hline \multirow[t]{2}{*}{ Infrastructures } & \multirow[t]{2}{*}{13,19} & Most industries are still using old machines and production equipment & 12,80 & 2,73 & 0,35 \\
\hline & & Industry has not been able to utilize the existing market potential & 4,23 & 2,47 & 0,10 \\
\hline \multirow[t]{2}{*}{ Market/Marketing } & \multirow[t]{2}{*}{12,30} & Fluctuation of the income and production levels & 4,23 & 2,14 & 0,09 \\
\hline & & Most of the industries has not had an adequate marketing network in export markets & 4,23 & 2,53 & 0,11 \\
\hline Product Result & 12,50 & Industry has not been able to produce the products with lower prices than competitors & 12,56 & 2,40 & 0,30 \\
\hline \multirow{2}{*}{ Production Process } & \multirow{2}{*}{12,20} & Industry could have not fully utilize the installed capacity (not efficient) & 6,22 & 2,60 & 0,16 \\
\hline & & Most industries are still using an older, less efficient technology & 6,22 & 2,73 & 0,17 \\
\hline Policy/Strategy & 12,00 & Only a small part of industry that has $R \& D$ policy & 11,79 & 2,67 & 0,31 \\
\hline \multirow{2}{*}{ Financing } & \multirow{2}{*}{11,51} & Most industries are still facing capital constraints & 5,68 & 2,93 & 0,17 \\
\hline & & The profitability of the industry tends to be fluctuated & 5,68 & 2,60 & 0,15 \\
\hline Total & 100,00 & & 100,00 & & 2,69 \\
\hline
\end{tabular}

Source: Primary Data (Processed)

Related to human resources, the strength of the textile industry is on its adequate amount of labor. However, the availability of skilled labor and the low level of productivity of human resources become
For infrastructure key factors, the strength owned by the textile industry is partly machinery and tools that are adequate. But the weakness is most industries still use the old machines and tools. It also occurs 
in Pakistan textile industry that generally still using outdated machines (Aamar, 2012). Correspondingly, the weakness related to production process still using old technology which is inefficient and has not fully utilize the installed capacity. The strength is part of the industry use modern technology and have the ability to adopt the technology. Therefore, restructuring machinery by the government (Ministry of Industry) needs to be effectively improved, so it will provide an enormous impact on the rejuvenation of the old machines in the textile industry.

Ministry of Industry (2014) revealed that according to the data from the Agency of Assessment Policy, Climate and Industrial Quality (BPKIMI), has allocated a budget of Rp1.10 trillion for restructuring program of machinery/textile industry equipment since 2007-2011. Through the restructuring program of the machinery, each industries that restructure their machine by buying machinery from abroad will receive $10 \%$ incentive of funds for purchasing the machines and when they buy machines from domestic industry, they will receive $15 \%$ intensive . Machine restructuring program had a positive impact on increasing foreign exchange earnings from textile commodities exports, and increased labor absorption in the textile industry.

Related to market/marketing, the strengths of the industries are the experience and ability to market their products, and they already have an adequate marketing network in the domestic market. While their weakness is not able to utilize the existing market potential, most of the industries have not had a marketing network in the export market as well as fluctuating income and production. Correspondingly, the disadvantage of the product is not yet able to produce products with lower prices than competitors. Besides these weaknesses, the strength of the industry is their ability to produce quality product continuously, fulfill the national/international standards, meet the consumer preferences and have the ability to design innovative products. Some of the strengths of the market/marketing and products need to be developed by the textile industry so that it has competitive advantages in the marketplace. In this context, the role of research and development ( $R$ \& D) becomes important, both in terms of market and product research. However, Asmara et al (2012) showed that only a small proportion of the textile industry (13.04 percent), and industrial textile products (8.11 percent), has $\mathrm{R} \& \mathrm{D}$. Moreover, he also revealed that the textile industry, $R \& D$ undertaken include product innovation, production efficiency, market survey and management. While the textile products industry, R \& D conducts more limited on product innovation and production efficiency.

Related to policy/strategy, the strengths of the textile industry are some of the industries have strategies to face the competition. Meanwhile, the weakness is only a small part of industry that has R \& D policy. Asmara, Purnamadewi, and Meiri (2013) revealed that to face the competition, the strategy undertaken by the industry include the strategic price and nonprice strategy (product, promotion and distribution). On the pricing strategy, the textile industry generally sets the price based on cost plus profit. Meanwhile, related to the products, generally is to maintain/ improve product quality, while for strategy of products development/innovation, textile industry barely did it.

The strength of the textile industry related to financial is to have an alternative source of capital. Meanwhile, the weaknesses are the industry facing the problem of capital and the profitability of the industry that tend to be fluctuated. This shows that the financial support from the government/financial institution needed to strengthen the capital structure of the textile industry.

\section{Analysis of External Factors of Indonesian Textile Industry}

Identification of external factors (opportunities and threats) are presented in Table 5 and Table 6 . Related to raw materials, the opportunities of the textile industry are the ease for obtaining imported raw materials, synthetic raw material supply of domestic and import tax refunds. Meanwhile, the threats facing the industry are the dependence (fiber and fabric) on imported raw materials and raw material prices are likely to increase. Taking into account the internal and external conditions, the increased production of domestic raw materials and innovation development of substitute raw materials can be an alternative solution to be considered by the government and industry. 
ISSN 1412 - 3681

Table 5 Matrix of Opportunities Analysis of Indonesian Textile Industry

\begin{tabular}{|c|c|c|c|c|c|}
\hline Key Factor & Weight & Opportunities & Weight & Rating & Value \\
\hline & & Ease for obtaining imported raw materials & 4,52 & 2,38 & 0,11 \\
\hline \multirow[t]{2}{*}{ Raw Materials } & 13,19 & Synthetic raw materials (polyester) are supplied by domestic products & 4,52 & 2,53 & 0,11 \\
\hline & & Availability of labor in sufficient numbers & 4,27 & 2,33 & 0,10 \\
\hline Human Resources & 13,10 & The government encourages vocational education and facilitate for educational and training & 4,27 & 2,43 & 0,10 \\
\hline \multirow[t]{2}{*}{ Infrastructures } & 13,19 & $\begin{array}{l}\text { The government continues to improve and build main infrastructures (roads, electricity, ports, } \\
\text { water, etc.) }\end{array}$ & 6,40 & 2,53 & 0,16 \\
\hline & & Domestic and export markets are increasingly opened & 4,23 & 3,33 & 0,14 \\
\hline Market/Marketing & 12,30 & Support/facilitation of the government for increasing exports & 4,23 & 2,47 & 0,10 \\
\hline Production Process & 12,20 & $\begin{array}{l}\text { There are government supports for the development of an integrated industrial zones and } \\
\text { bonded zones }\end{array}$ & 6,22 & 2,47 & 0,15 \\
\hline \multirow[t]{2}{*}{ Policy/Strategy } & 12,00 & $\begin{array}{l}\text { Government support to continue developing the national industry (textile industry entered as } \\
\text { a strategic industry) }\end{array}$ & 11,79 & 2,87 & 0,34 \\
\hline & & National banking condition is getting better & 3,79 & 2,80 & 0,11 \\
\hline \multirow[t]{2}{*}{ Financing } & 11,51 & Sources of financing opportunities from inside / outside the country & 3,79 & 2,20 & 0,08 \\
\hline & & Facilitation of government in financing & 3,79 & 2,20 & 0,08 \\
\hline Total & 100 & & 100,00 & & 2,67 \\
\hline
\end{tabular}

Source: Primary Data (Processed)

Table 6 Matrix of Threats Analysis of Indonesian Textile Industry

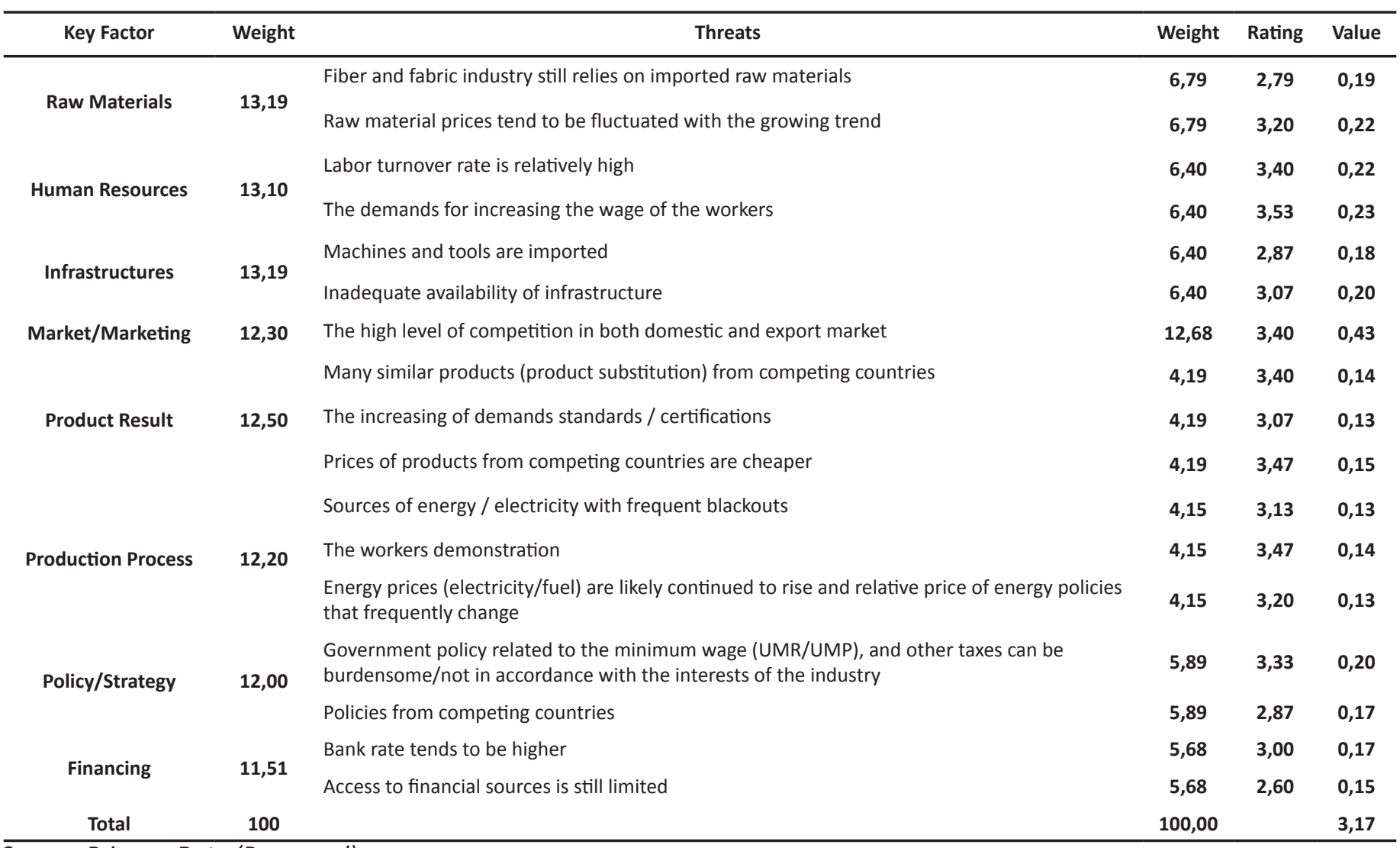


Related to human resources, the opportunities of the textile industry is an adequate number of workers, government support in vocational education and also educational and training as well as the level of the low wages. The threats are the increasing of wage demand and labor turnover rate is high. Therefore, what needs to be done is to build the harmonization of industrial relations between the company and the employees which getting better. In this context, government / regional government is required to become a mediator that is able to formulate a winwin solution policy for both parties, so the business climate becomes more favorable. Meanwhile in China, labor costs are still low and have not increased over the last five years (Anonymous, 2005).

Opportunities in the infrastructure sector are the facilitation of government in the procurement of machinery and efforts to continuously improve main infrastructure. Meanwhile, the threats are the availability of inadequate infrastructure and imported machinery. Along with it, the threat faced from the side of the production process is the frequent power outages, the price of energy (electricity / fuel) which tends to rise and also labor demonstrations. The chances are the evolving production technology and the development of an integrated industrial zones and bonded areas. Therefore, the increasing of infrastructures availability needs to be pursued by the government and industry to ensure the sustainability of efficient production process.

Related to the marketing, the opportunities of the industry are the domestic and export markets that continues to open. Government support in increasing exports and increasing market demand. The threats facing is the high level of competition in both domestic and export market. Correspondingly, in terms of products, the threats that may be faced are there many similar products and product prices that cheaper than competing countries as well as the increasing of certification demand. While the chances are the price of products in the international market are likely to increase. The development of prices of these products are the main opportunities (highest scoring) for the textile industry. On the other hand, the high level of competition is a major threat faced by textile industry. These findings indicate that the improvement of industrial competitiveness becomes the key for reaching opportunities and facing the threats. Asmara et al (2013a) concluded that the Indonesian fiber and garment industry product have comparative advantages (competitive) in the international market, but the industrial yarn products do not have comparative advantages (low competitive).

Government support for the development of national industry and facilitation of financing, national banking conditions that are getting better as well as the openness of financing sources whether inside or outside the country, becomes an opportunity that is related to the aspects of policy and financing. Meanwhile, the threat related to these two aspects are: policies regarding the minimum wage, taxes and other burdensome to the industry, the policy of competitor countries, interest rates are likely to increase, and limited access to capital resources. Therefore, in this context, the synchronization of policies and coordination between institutions (interministerial, central and local government) becomes more crucial.

\section{Strategies for Strengthening Indonesian Textile Industry Structure}

The calculations show that the IFE (strengthweakness) matrix is positive (+), i.e. 0.08 , while the EFE (opportunities-threats) matrix is negative (-), i.e. -0.50 (Table 7). Thus the position of Indonesian textile industry is in quadrant II (positive, negative), indicating that the textile industry not only has strengths, but also face the threats (Figure 4).

\section{Table 7 IFE and EFE Matrix of Strategies for Strengthening Indonesian Textile Industry Structure}

\begin{tabular}{cccccc}
\hline & Internal Matrix & \multicolumn{3}{c}{ External Matrix } \\
\hline $\mathrm{S}$ & $\mathrm{W}$ & Total & $\mathrm{O}$ & $\mathrm{T}$ & Total \\
2,77 & $-2,69$ & 0,08 & 2,67 & $-3,17$ & $-0,50$ \\
\hline
\end{tabular}

Pearce and Robinson (2004) revealed that recommendation strategy for organizations that is in Quadrant II (positive, negative) is Diversification Strategy. Organizations face a number of tough challenges that are expected to experience difficulties when just resting on the previous strategy and suggesting to immediately multiply diverse tactical strategies. Thereby, strengthening the structure of the textile industry in Indonesia needs to be formulated 
in a variety of alternative strategies (diversification strategy). The results of the identification of critical success factors (a key factor) internal and external form the basis for formulating alternative strategies.

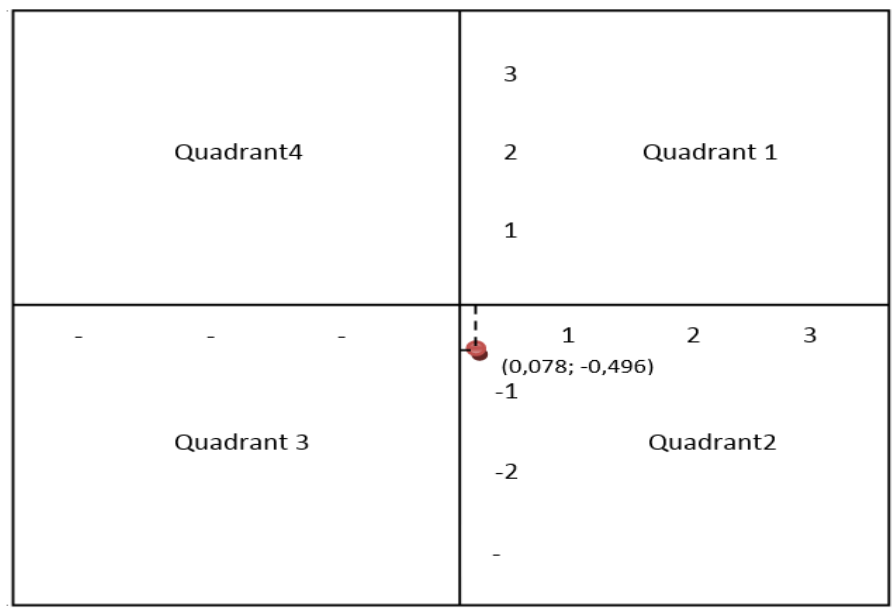

Figure 4 Analysis of Strategies for Strengthening Indonesian Textile Industry Structure

Based on the internal and external key factors, the diversification strategy of strengthening the Indonesian textile industry structure that can be identified are presented in Table 8.

\section{Priority Strategies for Strengthening Indonesian} Textile Industry Structure

After the formulation of strategies to strengthen the Indonesia's TPT structure using SWOT matrix based on internal and external strategic information factors from IFE and EFE matrix, the last stage is the selection of priority strategies or the best strategy by using analytical tools, Quantitative Strategic Planning Matrix (QSPM). QSPM is based on the aim to acquire the best priority strategythat is interesting to be implemented in accordance with the direction of government policy and the conditions of its own textile industry.

The determination of the interest on QSPM conducted through FGD by industries, government, and academician. Based on these discussions determined 17 most important strategies implemented by the Indonesian textile industry. The results of QSPM analysis are in Appendix 1. The results of QSPM analysis for strengthening Indonesian textile industry structure are briefly shown in Table 9.

Table 8 Diversification Strategies for StrengtheningIndonesian Textile Industry Structure

\begin{tabular}{|c|c|c|}
\hline Key Factor & & Strategy \\
\hline \multirow{3}{*}{ Raw Materials } & S1 & Maintain and utilize alternative sources of procurement of raw materials (domestic and imported) \\
\hline & & \\
\hline & S2 & Making development/innovation of alternative raw materials that can be produced domestically. \\
\hline \multirow{5}{*}{ Human Resources } & S3 & Increasing the number of skilled workers in the textile field. \\
\hline & S4 & Increasing the productivity of human resources in the field of textile. \\
\hline & & \\
\hline & S5 & The development of education and training programs in the field of textile. \\
\hline & S6 & The development of decent wage system for employees and industry. \\
\hline \multirow{2}{*}{ Infrastructure } & S7 & Increasing the intensity ofrenovation/restructuring machinery program. \\
\hline & S8 & Increasing the quantity and quality of major infrastructure, especially electricity. \\
\hline \multirow{2}{*}{ Marketing } & S9 & Increasing competitiveness of the textile industry. \\
\hline & S10 & The development of appropriate marketing strategies for targeted market segmentation (domestic / export). \\
\hline \multirow{3}{*}{ Product Result } & S11 & Improving the quality and innovation of products according to consumer preferences. \\
\hline & & \\
\hline & S12 & The development of the competitive product pricing strategy. \\
\hline \multirow{2}{*}{ Production Process } & S13 & Optimizing the utilization of the machine/tool suitable capacity. \\
\hline & S14 & Improved technology adoption. \\
\hline \multirow[t]{2}{*}{ Policy/Strategy } & $\mathrm{S} 15$ & Harmonization of policies that promote a conducive business climate. \\
\hline & S16 & The development of financing schemes that fit the needs of the industry. \\
\hline \multirow[t]{2}{*}{ Financing } & & \\
\hline & S17 & Tax/non-tax incentives for prospective industries. \\
\hline
\end{tabular}


Table 9 The Results of QSPM Analysis for Strengthening Indonesian Textile Industry Structure

\begin{tabular}{ccc}
\hline Strategy & STAS & Rating \\
\hline S1 & 9.93 & 3 \\
S2 & 9.50 & 10 \\
S3 & 9.65 & 8 \\
S4 & 9.71 & 6 \\
S5 & 9.17 & 12 \\
S6 & 9.52 & 9 \\
S7 & 9.40 & 11 \\
S8 & 9.12 & 13 \\
S9 & 9.95 & 2 \\
S10 & 9.02 & 16 \\
S11 & 9.05 & 15 \\
S12 & 9.99 & 1 \\
S13 & 9.12 & 14 \\
S14 & 9.69 & 7 \\
S15 & 9.84 & 5 \\
S16 & 9.93 & 4 \\
S17 & 8.61 & 17 \\
\hline & & \\
\hline
\end{tabular}

In Table 9 it can be seen that, the most interesting strategy or the most priority strategy is the development of a competitive product pricing strategy (S12) with STAS value of 9.99. The next priority strategy is the improvement of the textile industry competitiveness (S9), maintain and utilize various alternative sources of procurement of raw materials (domestic and imported) (S1) with STAS scores respectively 9.95 and 9.93 .

The reasons to prioritize the development of competitive price products strategy are the prices of Indonesian textile products are less able to compete with textile products from other countries, especially China. Indonesian textile products have higher prices of Chinese textile products due to the high cost of transportation and production costs, and also the tax rate specified in producing apparel in Indonesia, which makes the price of Indonesian textile products becomes uncompetitive in local market even in international market (Hartono, 2013).

Although the quality of Indonesian textile products is similar and even superior to the quality of textile products of other countries, but consumers still consider to the price of these products which will affect their purchasing decisions. Uncompetitive price of Indonesian textile products due to high raw material prices, as most raw materials are imported and some types of raw materials are taxed imports, such as cotton imports are subject to PPN of 10 percent for each purchase. According to Widodo and Ferdinand (2010), the national cotton fiber needs will increase due to rise in the volume of industrial production of textiles and textile products. With the revocation of cotton fiber export subsidies of developed countries, the world cotton price will be more expensive, thus the dependency on imported cotton fiber has to be suppressed by spurring domestic fiber production.

In addition, uncompetitive prices are also influenced by the high level of wage (UMR) imposed as well as the increasing of basic electricity tariff. There are also differences from raw material prices and wages (UMR) in some areas, for example the price of raw materials and UMR in East Java province higher than in the West Java, where it will be weighed on the textile industry in East Java.

\section{CONCLUSIONS AND RECOMMENDATIONS}

The high level of competition in the textile industry products is a real phenomenon faced by Indonesian textile industry. Even the level of competition is one of the main threats to the continuity of the textile industry in Indonesia. In addition, there are various threats from external side, internally national textile industry also has many weaknesses. The inability to ensure the availability of raw materials (quantity, quality and continuity) is one of the major weaknesses of Indonesian textile industry. Some other disadvantages are related to the machineries and tools that are outdated, and limited skilled human resources.

However, Indonesian textile industry also has a wide range of power that can be developed so that the existence of Indonesian textile industry is maintained. It have a variety of alternative sources of procurement of raw materials (domestic / imported), an adequate amount of labor and machinery (modern) in most industries are some of the strength of the Indonesian textile industry. On the external side, the increasing of product prices in the international market, the government's support, emerging technology and domestic/export market potential increasingly opened are partly the opportunities that can be 
JURNAL BISNIS \& MANAJEMEN

ISSN 1412 - 3681

utilized by Indonesian textile industry which can continue to develop.

With a variety of internal and external conditions that are evolved, Indonesian textile industry which is on SWOT quadrant is in quadrant 2 (positive, negative). That means that the Indonesian textile industry has power, but it still faces the threat. Therefore, the Indonesian textile industry is encouraged to develop a diversified strategy for strengthening textile industry structure. Based on QSPM analysis, there are 5 most prioritized strategies to be implemented: (1) develop the competitive price products strategy, (2) improve the competitiveness of the textile industry, (3) Maintain and utilize various alternative source procurement of raw materials (domestic and imported), (4) develop the financing schemes that fits the needs of the industry, and (5) harmonizethe policies that promote a conducive business climate.

Related to the programs that have been implemented by the government (Ministry of Industry), needs to be continued. Machinery revitalization program should be continued, and it can be increased its effectiveness that needs to be evaluated, so that many challenges still encountered in its implementation that can be addressed immediately. Correspondingly, Ministry of Industry also needs to develop other programs, particularly related to the strengthening of raw materials aspects, human resources, infrastructures and markets/marketing. This is based on the consideration that those four aspects are the main aspect for strengthening the textile industry structure in Indonesia.

\section{REFERENCES}

Aamar, S. (2012). Risk Analysis of the Pakistani Textile Industry: A Macro Analysis. Laurea University of Applied Sciences. Retrieved from: http://www.theseus.fi/bitstream/ handle/ 10024/43815/Final_Thesis_ Aamar\%20Sohail.pdf?sequence=1.

Ahmed. (2013). An Analysis of The Change and Volatility in The Apparel Industry of Bangladesh after MFA Era. Journal of Textile and Apparel, Technology and Management, 8(1), 1-11.
Jurnal Bisnis \& Manajemen, 2016, Vol. XVII, No. 1, 33-47

Anonim. (2005). Study on China's Textiles \& Clothing Industry and its Market Expansion Strategy. Retrieved from. http://trade.ec.europa. eu/doclib/docs/2005/december/tradoc_ 126633. pdf.

Anonim. (2013). 2013, Pemerintah Targetkan Kirim 2.500 Peserta Magang Kerja ke Jepang. Retrieved from: http://www.beritasatu. com/ekonomi/94848-2013-pemerintahtargetkan- kirim-2500-peserta-magangkerja-ke-jepang.html.

Anonim. (2014). Pemerintah Prioritaskan Restrukturisasi Mesin. Retrieved from: http://www.neraca.co.id/article/37467/ Pemerintah-Prioritaskan-RestrukturisasiMesin.

Asmara, A., Purnamadewi, Y.L., Mulatsih, S., \& Novianti, T. (2012). Strategi Penguatan Struktur Industri Tekstil dan Produk Tekstil dalam Mereduksi Pengangguran di Indonesia. Laporan Akhir Tahun Pertama, Penelitian Prioritas Nasional Master Plan Percepatan dan Perluasan Pembangunan Ekonomi Indonesia (MP3EI). Institut Pertanian Bogor.

- (2013a). Strategi Penguatan Struktur Industri Tekstil dan Produk Tekstil dalam Mereduksi Pengangguran di Indonesia. Laporan Akhir Tahun Kedua, Penelitian Prioritas Nasional Master Plan Percepatan dan Perluasan Pembangunan Ekonomi Indonesia (MP3EI). Institut Pertanian Bogor.

(2013b). Faktor-Faktor yang Memengaruhi Perkembangan Investasi Pada Industri Tekstil dan Produk Tekstil (TPT) Indonesia. Jurnal Manajemen Teknologi 12(2): 140-160.

Asmara, A., Purnamadewi, Y.L., Mulatsih, S., \& Meiri, A. (2013c). Development of Textile and Clothing Industry Performance and The Influence Factors In Java Economic Corridor. Conference Proceedings, The 23rd 
Pacific Conference of The Regional Science Association International (RSAI) \& The 4th Indonesian Regional Science Association (IRSA) Institute.

Asmara, A., Purnamadewi, Y.L., Meiri, A. (2013). Analisis Struktur, Perilaku, dan Kinerja Industri Tekstil dan ProdukTekstil Indonesia. Jurnal Bisnis dan Manajemen 14(2): 103110.

Bilalis, N., Wassenhove, L.N.V., Maravelakis, E., Enders, A., Moustakis, V., \& Antoniadis, A. (2006). Insights from research An analysis of European textile sector competitiveness. Measuring Business Excellence, 10(1), 2735.

David, F.R. (2006). Manajemen Strategis: Konsep. Edisi ketujuh. Jakarta: PT. Prenhallindo.

Firdaus, A.H. (2007). Analisis Daya Saing dan FaktorFaktor yang Mempengaruhi Ekspor Tekstil dan Produk Tekstil Indonesia di PasarAmerika Serikat. [Skripsi]. Bogor: Institut Pertanian Bogor.

Haliding, S. (2010). Review Implementasi CAPTA dan Ketidakadilan Perdagangan Bebas. Kompasiana. Retrieved from: http://m. kompasiana.com/post/read/262374/1/ implementasi-capta-dan-ketidakadilanperdagangan-bebas.html.

Hartono, R. (2013). Pengaruh Kerjasama AseanChina Free Trade Agreement (ACFTA) Terhadap Pasar Domestik Produk Tekstil Indonesia (2010-2012). eJournal Ilmu Hubungan Internasional, 1(4), 1077-1084.

Hermawan, I. (2011). Analisis Dampak Kebijakan Makroekonomi Terhadap Perkembangan Industri Tekstil dan Produk Tekstil Indonesia. Buletin Ekonomi Moneter dan Perbankan: 373-407.

Kadin Indonesia. (2007). Ringkasan Eksekutif: Visi 2030 dan Roadmap 2010 Industri Nasional. Jakarta: KADIN Indonesia.
Kenta, G. (2007). Industrial Upgrading of the Vietnamese Garment Industry: An Analysis from the Global Value Chains Perspective. RCAPS Working Paper No.07-1.

Khan, M.S., Ahmed, S., Evans, A.E.V., \& Chadwick, M. (2009). Methodology for Performance Analysis of Textile Effluent Treatment Plants in Bangladesh. Chemical Engineering Research Bulletin, 13, 61-66.

Kinnear, T.C., \& Taylor Jr. (1996). Marketing Research: an Applied Approach. 5th Ed. New York: McGraw-Hill,Inc.

MacDonald, S., Pan S., Somwaru, A., Tuan, F. (2004). China's Role in World Cotton and Textile Markets. Selected Paper prepared for presentation at the American Agricultural Economics Associaation Annual Meeting, Denver, Colorado, August, 2004. Retrieved from: http://www.aaec.ttu.edu/ceri/ newpolicy/publications/presented $\% 20$ papers/chinesepaper.pdf.

NSDC. (2011). Human Resource and Skill Requirements in the Textile Industry. New Delhi: National Skill Development Corporation.

Nur. (2013). CPO dan Tekstil Paling Banyak Dapat Pembiayaan Exim bank. Liputan 6. Retrieved from: http://bisnis.liputan6. com/read/544316/cpo-dan-tekstilpaling-banyak-dapat-embiayaaneximbank\#sthash.fviHrSHh.dpuf

Pearce D., \& Robinson, E. (2004). Manajemen Strategik. Formulasi, Implementasi dan Pengendalian. Jilid Satu. Alih Bahasa Terbitan Pertama. Jakarta: Bina Aksara.

Tresnaningtyas, A. (2009). Dibanding Impor, Kualitas Tekstil Domestik Lebih Baik. KOMPAS. Retrieved from: http://female.kompas.com/ $\mathrm{read} / 2009 / 05 / 08 / 11162357 /$ Dibanding. Impor. Kualitas.Tekstil.Domestik.Lebih.Baik

Widodo, K., Ferdiansyah, E. (2010). Optimasi Kinerja Rantai Pasok Industri Tekstil dan Produk 
Tekstil Indonesia Berdasarkan Simulasi World Economic Forum. (2013). The Global Sistem Dinamis. AGRITECH, 30(1), 46-55. Competitiveness Report 2013-2014. World Economic Forum. Geneva. 